\title{
Dendrogeomorphology and high-magnitude snow avalanches: a review and case study
}

\author{
D. R. Butler ${ }^{1}$ and C. F. Sawyer ${ }^{2}$ \\ ${ }^{1}$ Department of Geography, Texas State University-San Marcos, San Marcos, TX 78666-4616 USA \\ ${ }^{2}$ Department of Earth Sciences, University of South Alabama, Mobile, AL 36688-0002 USA
}

Received: 3 January 2008 - Revised: 6 March 2008 - Accepted: 10 March 2008 - Published: 4 April 2008

\begin{abstract}
The application of the principles of dendrogeomorphology for the dating of high-magnitude snow avalanches is well established in the natural hazards literature. A variety of methodologies are employed by different authors, however, and no standardization currently exists for appropriate sample sizes, the issue of "weighting" certain tree-ring responses as more important than others, or the minimum number of responding trees required in order to infer an avalanche event. We review the literature of dendrogeomorphology as it applies to snow avalanches, and examine the questions of sample size, type of ring reactions dated and weighted, and minimum responses. We present tree-ring data from two avalanche paths in the Rocky Mountains of Montana, USA, from trees uprooted by major snow avalanches in the winter of 2002. These data provide distinct chronologies of past avalanche events, and also illustrate how the critical choice of a minimum Index Number can affect the number of avalanche events in a final chronology based on tree-ring analysis.
\end{abstract}

\section{Introduction}

Snow avalanches in mountains around the world descend from alpine and subalpine reaches into lower elevations where they are a hazard to human activity. Avalanches pass through forests in their descent to valley floors, damaging and destroying trees in their transit. If avalanching occurs sufficiently often within a well-defined topographic position, i.e. an avalanche path, mature forest is precluded from occupying the avalanche path which ecologically functions as a corridor (sensu Butler, 2001). In such cases, a patchwork of mature forest and gaps of flexible shrubs, herbs,

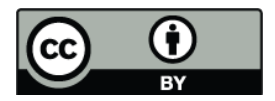

Correspondence to: D. R. Butler (db25@txstate.edu) and low-growing trees instead occupy the avalanche path (Schaerer, 1972; Butler, 1979; Johnson et al., 1985; Johnson, 1987; Erschbamer, 1989; Patten and Knight, 1994; Kajimoto et al., 2004). This vegetation is distinctly less fireprone than adjacent forests, and avalanche paths have been identified as natural fuel breaks that can disrupt the propagation of forest fires (Malanson and Butler, 1984a; Suffling, 1993). Both lateral/transverse (Ives et al., 1976; Malanson and Butler, 1984b, 1986) and longitudinal (Schaerer, 1972; Butler, 1979; Johnson, 1987) zonation may occur within an avalanche path, indicative of avalanches of varying scale and magnitude in the recent history of the path. Avalanche velocities and impact pressures can be estimated from the characteristics of trees broken with avalanche paths (Mears, 1975; Ives et al., 1976; Butler, 1979).

Because the nature of shrub and low-tree growth on avalanche paths provides only a general estimate of time since avalanching, rather than a year-specific indication, the use of damage to tree rings in trees within and along the margins of avalanche paths has become well established in the natural hazards literature using principles of dendrogeomorphology elucidated by Alestalo (1971) and Shroder (1980). What is not well established, however, is a uniform agreement concerning minimum sample sizes and minimum number of tree-ring responses necessary for the recognition of a past avalanche event. Varying numbers of sampled trees are employed in constructing chronologies of past avalanches, the question of how many sampled trees need to illustrate distinct tree-ring responses is also open to question, and the type of dated tree-ring responses varies among studies. It is the purpose of this paper to:

1. review the general methodologies employed in the study of snow avalanches using tree-ring analysis;

2. examine the type of tree-ring responses most typically employed in construction of high-magnitude snow

Published by Copernicus Publications on behalf of the European Geosciences Union. 
avalanche chronologies, and how differing responses are weighted or ranked;

3. examine the minimum number of samples illustrating tree-ring responses to snow avalanche disturbance; and

4. illustrate how variations in sample size and minimum number of responding samples can produce variations in a chronology of high-magnitude snow avalanches. The first three objectives are accomplished through a literature review, and the fourth objective is completed by examining tree ring samples collected in a mountain region of northwest Montana, USA, where well-developed historical chronologies of past highmagnitude snow avalanching, based on archival and dendrochronological data, exist.

\section{Review of methodologies employed in the creation of avalanche chronologies}

The use of tree rings for reconstructing chronologies of snow avalanching has a decades-long history, with increasing sophistication obviously characterizing more recent applications. Here we examine key papers that have used principles of dendrogeomorphology for producing chronologies of avalanche damage.

In general, the morphological criteria examined in trees damaged by snow avalanching are the same as those in other areas of dendrogeomorphology (see Stoffel, 2006; Stoffel and Bollschweiler, 2008), e.g. the creation of corrasion scars, onset of reaction wood (compression wood in conifers and tension wood in deciduous trees) as a result of tilting, onset of suppressed or released rings, leader growth, root exposure or burial, nudation, and succession (Potter, 1969; Alestalo, 1971; Ives et al., 1976; Carrara, 1979; Shroder, 1980; Butler, 1987a; Butler et al., 1987; Hansen-Bristow and Birkeland, 1989). Of this variety of tree-ring responses to the geomorphic event of snow avalanching, the first three by far have been the most widely utilized in creating to-the-year chronologies of avalanching, and seem to be the most accurate (Burrows and Burrow, 1976; Carrara, 1979). Recently, the onset of traumatic resin ducts/canals within annual rings of damaged trees has been used as a new valuable annual dating tool (Larocque et al., 2001; Stoffel et al., 2006; Casteller et al., 2007). This tool can also be an indicator of seasonality that can help distinguish between scars and reaction wood created by avalanching versus other processes such as debris flows (Stoffel et al., 2006). Nudation and subsequent succession can be dated in general through examination of the maximum age of trees growing on a previously denuded site, but such efforts are only estimates given the variations in ecesis interval between the denuding event and subsequent tree establishment (Schaerer, 1972; Shroder, 1980).

Dendrogeomorphological reconstructions of snowavalanche chronologies have, like other natural hazard chronologies described by Stoffel and Bollschweiler (2008), been primarily employed in studies in North America and Europe. In North America, tree rings have been successfully employed to reconstruct avalanche chronologies in both the USA and Canada. In the United States, such studies have been carried out in the Front Range (Ives et al., 1976; Carrara, 1979; Rayback, 1998) and Sangre de Cristo Range (Bryant et al., 1989) of Colorado; the Grand Teton Range (Patten and Knight, 1994) and Absaroka Mountains of Wyoming (Potter, 1969); the Wasatch Range of Utah (Hebertson and Jenkins, 2003; Jenkins and Hebertson, 2004); the Lewis Range of Glacier National Park, Montana (Butler, 1979; Butler and Malanson, 1985; Reardon et al., 2004; Pederson et al., 2006; Reardon et al., 2008); and the Cascade Range of Washington (Smith, 1973; Cushman, 1981). In Canada, dendrogeomorphology has been successfully employed in the mountains of British Columbia (Schaerer, 1972; Sandford, 1992), in Banff National Park (Frazer, 1985) and the Kananaskis region in Alberta (Niemann, 1982; Johnson et al., 1985; Johnson, 1987), and the mountains of the central Gaspé Peninsula of Québec (Larocque et al., 2001; Boucher et al., 2003; Dubé et al., 2004; Germain, 2005).

Although more recently than in North America, dendrogeomorphological studies of snow avalanches in Europe are becoming increasingly common. Ward (1985) used tree-ring damage, focusing on corrasion scars, to examine avalanches in the Cairngorms of Scotland. Muntán et al. (2004) presented the first results of tree-ring dating of avalanches in the Pyrenees. Stoffel et al. (2006) illustrated how to distinguish between trees damaged by debris flows and snow avalanches on a runout cone in Switzerland, and Casteller et al. (2007) dated avalanche events in eastern Switzerland using reaction wood formation, abrupt growth changes (suppression/release), and traumatic resin ducts.

Recent other studies external to North America and Europe have been conducted in Argentina and Japan. Kajimoto et al. (2004) summarized a great deal of the Japaneselanguage literature, and primarily used abrupt changes in ring width and patterns to date major avalanche events in northern Japan. Mundo et al. (2007) used corrasion scars and abrupt increases (release) in tree growth to identify major avalanches in the Tierra del Fuego region of Argentina.

\section{Tree-ring responses and weights}

Most seasoned dendrogeomorphologists are aware of the necessity for strong cross-dating with individual trees, i.e. they look for multiple tree-ring reactions to the same event within the circumference of a single disc or vertically within a number of cores or discs. This cross-dating is necessitated by the varying strength of ring responses that may be induced by an individual avalanche event. The strength of onset of reaction wood (as measured by darkness, ring thickness, and 
degree of circumference coverage of the reaction wood crescent) is one factor, for example, that varies from avalanche event to avalanche event within a single tree, yet reactions of varying strength are nevertheless equally viable for dating an event. Choice of ring responses - must a corrasion scar be present to convincingly evoke an avalanche event? are suppression/release patterns equal in quality to reaction-wood onset patterns? does a wide reaction-wood ring provide a stronger response than a narrow, or less laterally extensive, reaction-wood ring? - varies among dendrogeomorphological practitioners and with experience, and so some workers have attempted to standardize the quality of tree-ring reactions. Frazer (1985), under the supervision of B. Luckman of the University of Western Ontario, introduced the first such system. He identified four classes (A-D) of reaction quality, where Class A reactions (tree death; reaction wood duration of a minimum of 2 years, encompassing more than $90^{\circ}$ of a tree's circumference; scars encompassing $>45^{\circ}$ of a tree's circumference; and suppression/release ring width changes of at least $60 \%$ with a duration of a minimum of 5 years) are the strongest, with Classes B and C transitional to the weakest signals of Class $\mathrm{D}$ reactions (reaction wood response not meeting critical limits, corrasion scars covering $<10^{\circ}$ of the tree circumference, and a suppression or release patterns of any duration with only a minimum of $30 \%$ variation in ring width). Germain et al. (2005) adopted Frazer's (1985) system with minor modifications. Recently, Pederson et al. (2006) and Reardon et al. (2008) presented an alternate rating system that depends heavily on the presence of corrasion scars and reaction wood, but which is less quantitative in the measurements associated with ring-width variations and circumferential extent of reaction wood. They created five different ratings for avalanche-induced growth responses:

1. clear impact scar associated with obvious reaction wood or growth suppression;

2. clear scar, but no reaction wood or suppression of growth, OR, obvious reaction wood/suppression of growth that occurs abruptly after complacent or "normal" growth and that lasts for approximately three years;

3. well-defined reaction wood/suppression of growth, but only prevalent in 1 or 2 successive growth years;

4. reaction wood or growth suppression present but not well defined, OR, reaction wood present but formed when tree was young and more susceptible to damage from various environmental and biological conditions; and

5. same as 4 except reaction wood is very poorly defined, and slow onset may indicate other processes such as soil or snow creep may be primary causes (Pederson et al., 2006, p. 439).
At this time, there is no agreement among dendrogeomorphologists studying snow avalanche chronologies about which, if any, of these systems of "ring damage rating" should be employed, or indeed if such a semi-quantitative categorization is actually necessary for a skilled dendrogeomorphologist.

\section{The issues of sample size and minimum number of ring responses}

Most dendrogeomorphologists would agree that one damaged tree "doth not an avalanche event make", although Burrows and Burrows (1976, p. 30) stated that "one tree may provide information about many avalanche events, and this may constitute a suitably-sized sample." Stoffel et al. (2006) used growth disturbances from a single tree to infer an avalanche event for the period 1750-1850, due to the limited number of living trees extending back to that time period, but required strong growth disturbances in several trees for the period since 1850. No standard value exists, however, for the minimum number of trees needing to respond in order to invoke an avalanche event. Certainly variability in sample sizes exists (see Butler et al., 1987, for an examination of this question as it applies in general to dendrogeomorphology). The general "rule of thumb" is, of course, that "more is better". Time constraints, field logistics, and safety and monetary considerations are among the items that must be balanced when deciding upon a sample size. Ten clearly damaged trees, providing excellent corrasion scars and strong reaction wood, suppression/release, and/or traumatic resin duct onset may be sufficient for the development of a chronology on a single avalanche path, but 100 such trees would be better!

Once the damaged trees have been sampled and the treering reactions have been measured and plotted, is there a minimum number of the sampled group that should illustrate responses in order to firmly state "these reactions are created by avalanche-induced damage"? Butler and Malanson (1985) used an Index Number (the concept elucidated by Shroder, 1980) of $40 \%$ in their examination of high-magnitude avalanches in southern Glacier National Park, Montana, USA, where only years exceeding that value also had some limited form of historical documentation for avalanches in the region. Butler et al. (1987) and Bryant et al. (1989) also subsequently used this $40 \%$ threshold for the acceptance of an avalanche event. Obviously in those studies (Burrows and Burrow, 1976; Stoffel et al., 2006) where a single tree was used to infer an avalanche event, that inference was imposed by the limited number of trees available of a great age. For more recent years, Stoffel et al., (2006) do not calculate an Index Number, but depend on their experience and expertise in identifying strong growth disturbances to infer an avalanche (or debris flow) year. Dubé et al. (2004) and Germain et al. (2005) have settled upon the use of a $10 \%$ 


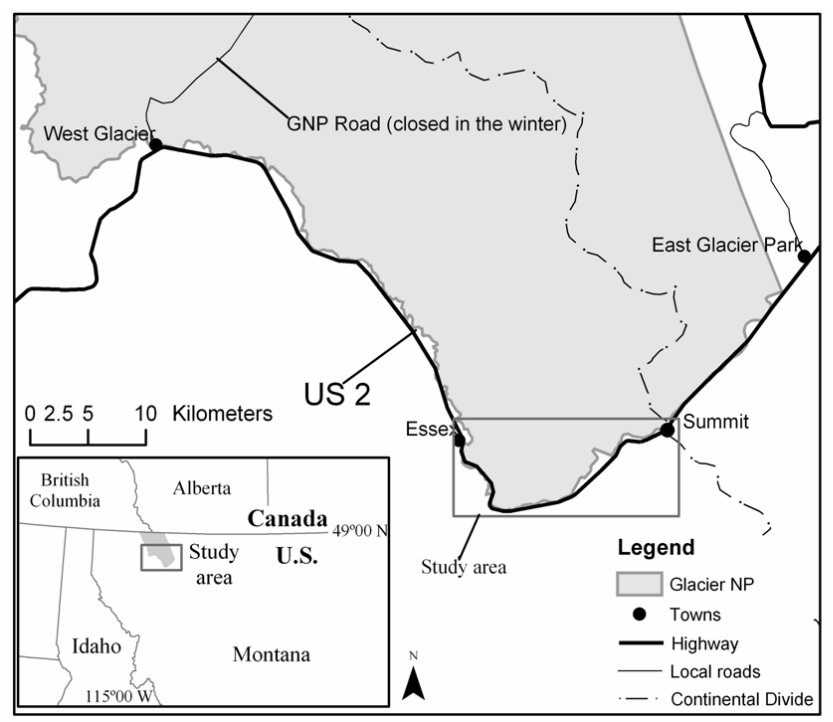

Fig. 1. Map of study region, southern Glacier National Park. The box notes JFS Canyon, located between Essex and Summit.

Index Number for the inference of avalanche events in the Gaspé Peninsula of Canada, and Pederson et al. (2006) and Reardon et al. (2008) have also adopted that figure in their work in Montana, USA. Below, we illustrate how the total number of avalanche years inferred from tree-ring damage is strongly controlled by the size of the Index Number utilized, and suggest that the $10 \%$ number may be too generous, at least in those cases without a very large sample size and some form of local historical corroboration.

\section{Variability in chronology construction based on min- imum number of ring responses}

\subsection{Study area}

In northwestern Montana, USA, over 40 avalanche paths are located within John F. Stevens Canyon, and snow avalanches there frequently disrupt highway and rail traffic on US Highway 2 (US 2), and the Burlington Northern - Santa Fe Railroad (BNSF) (Butler and Malanson, 1985; Butler 1986b, 1987b; Reardon et al., 2004; Sawyer and Butler, 2006). The avalanches originate primarily on unmanaged slopes to the north in Glacier National Park (GNP), with some coming from the adjacent National Forest (also unmanaged) to the south. This region is sparsely populated, but transportation through JFS Canyon serves as a vital link between several otherwise isolated communities. Avalanche closure of the railway tracks of the BNSF creates costly interruptions and stoppages in the transport of goods between Midwestern US cities and major Pacific ports. When US 2 is closed by avalanches, a $300-\mathrm{km}$ detour is required in order to drive from the western to the eastern side of GNP.
This region experiences short, mild summers and long, harsh winters. Climate data from Summit, Montana show average monthly temperatures of $-9.7^{\circ} \mathrm{C}$ in January and $13.8^{\circ} \mathrm{C}$ in July. Average temperatures remain below freezing five months of the year (November-March) (NCDC, 2006). Yearly precipitation averages $959 \mathrm{~mm}$, with January recording the heaviest snowfall at an average of over $1200 \mathrm{~mm}$.

Two avalanche paths in JFS Canyon are the focus of this study, the I-Beam path and the Shed 7 path. These avalanche paths are within a $10 \mathrm{~km}$ section of JFS Canyon (Fig. 1). Shed 7 has a southeast-facing slope orientation, whereas the I-beam path faces west-northwest. A tree-ring chronology for Shed 7 up through 1983 was reported by Butler and Malanson (1985). A general history of high-magnitude avalanche winters throughout JFS Canyon was provided by Butler (1986a, b), and this chronology was expanded and supplemented by Reardon et al. (2004) and Sawyer and Butler (2006). Avalanches were widespread (occurring on at least two different avalanche paths) in 1910, 1929, 1933, 1936, 1939, 1945, 1950, 1952, 1954, 1956, 1957, 1963, 1972, 1975, 1979, 1982, 1991, 1993, 1995, 1997, and 2002 (Sawyer and Butler, 2006).

In the winter of 2001-2002, widespread avalanching occurred throughout the JFS Canyon region, stopping traffic on both US 2 and the BNSF. Large, mature conifers were uprooted and deposited by avalanches in the furthest reaches of individual path runout zones, providing an opportunity for tree-ring sampling of downed trees without sacrificing living trees within or along the margins of avalanche paths. Cross-cut discs were collected from 10 such trees in the IBeam path and 12 trees in the Shed 7 path (avalanche path names are informal names used by the US Geological Survey and the BNSF). Species was recorded for each tree. Discs were sanded and examined under a binocular microscope, and years of occurrence of corrasion scars, onset of reaction wood, and suppression or release rings were recorded. A minimum of two radii per disc were recorded for internal cross-dating purposes, and each disc was also crossdated with the others in the sample group using standard eventresponse methodology (Shroder, 1980).

\subsection{The I-Beam path}

The trees sampled at the I-Beam path were all subalpine fir (Abies lasiocarpa). All but one of the samples extended back to at least 1945, providing several decades of new information for this previously undated path.

Signals of reaction wood onset and corrasion scarring by avalanching ( $>1$ tree per year) were recorded in 1945, 1947, 1952, 1954, 1959, 1964, 1972, 1974, 1979, 1982, 1987, 1991, 1996, and 1997, with all trees uprooted in 2002. Historical corroboration (Sawyer and Butler, 2006) exists for the avalanche winters of 1945, 1952, 1954, 1972, 1979, 1982, 1991, and 1997. Avalanching in 1996 was observed on an adjacent path (Hanging Tree) by the senior author, and may 
corroborate the 1996 date as well. The lack of total correspondence between the tree-ring and historical records is not surprising, given that the bulk of the historical record comes from the southeast- to southwest-facing avalanche paths farther up JFS Canyon, whereas recall that the I-Beam path has a west-northwest aspect.

\subsection{The Shed 7 path}

The Shed 7 tree-ring record devised here is based on discs from 9 Douglas-fir (Pseudotsuga menziesii), 2 subalpine fir, and 1 lodgepole pine (Pinus contorta) trees. Eight of the trees extend back to at least 1963, and 10 of the 12 date from at least 1968.

The tree ring record since 1963 showed signals of reaction wood onset and corrasion scarring by avalanching ( $>1$ tree per year) in 1971, 1972, 1976, 1979, 1982, 1985, 1987, 1989, and 1991. Butler and Malanson's (1985) original treering chronology for the period 1963-1983 showed avalanching in 1963, 1965, 1969, 1970, 1972, 1974, 1976, 1979, and 1982. That study focused on site-specific tree samples in distinct areas within the avalanche path, emphasizing the local geomorphology (sensu Stoffel and Bollschweiler, 2008), whereas the samples described here were all collected from the runout zone without knowledge of where in the path the sampled trees originated. The sampled trees here are corroborated by the historical record in 1972, 1979, 1982, and 1991.

\subsection{Issues with index numbers}

In the case of both the I-Beam and Shed 7 paths, the tree-ring chronology of past avalanche events is dependent on the cutoff for the minimum number of acceptable responding trees, i.e. on the Index Number value from which avalanching is inferred. Recall that Butler and Malanson (1985) and Butler et al. (1987) advocated an Index Number cut-off of $40 \%$, whereas more recent studies with greater numbers of samples (dozens vs. hundreds) suggest that Index Numbers as low as $10 \%$ are acceptable. In our study area, the recent expansion of the historical record of avalanching by Reardon et al. (2004) and Sawyer and Butler (2006) allows us to suggest that a 20\% Index Number is appropriate, rather than the more stringent $40 \%$ that was based on a significantly more limited historical record, for use with a small sample size of trees that are not in situ.

For the avalanche paths under examination here, the $20 \%$ Index Number provided a chronology of high-magnitude avalanche winters that largely mirrored the recently expanded historical record. Because of our small sample size, use of a 10\% Index Number would have required acceptance of an avalanche event based on only one tree, that was not in situ, something we are unprepared to do. Use of a higher Index Number also seemed unnecessary because of the detailed historical record available, and because doing so resulted in losses of avalanche winters with strong historical corroboration. When, for example, a $30 \%$ value was used, the resulting tree-ring chronologies from our avalanche paths present fewer high-magnitude avalanche events. The I-Beam path chronology would illustrate avalanching only in 1945, 1947, 1959, 1964, 1972, 1974, 1982, 1987, 1991, 1996, and 1997, a decline of 3 avalanche years recognized using a 20\% Index Number. The three years removed from the record include 1979, the year in which the most geographically widespread avalanching in recorded history occurred. Furthermore, the 2 sampled trees illustrating reactions in 1979 showed strong reactions, in the form of a distinct corrasion scar and intense onset of reaction wood. If a $40 \%$ Index Number was used for the I-Beam path, the number of avalanche years drops again, to $1947,1959,1964,1972,1982,1987,1991$, and 1996, a loss of an additional three years from the record including another year with strong historical corroboration (1945).

On the Shed 7 path, an Index Number of 30\% reduces the recorded avalanche years to 1971, 1976, 1979, 1982, 1987, and 1991. Use of a $40 \%$ value further reduces the record to only 1971, 1976, and 1979, even though strong historical corroboration exists for both 1982 and 1991.

\section{Conclusions}

It is clear from our preceding examples that selection of an Index Number value for specific sites must be tempered (where possible) with knowledge of the historical record as well as assessment of the nature of the tree-ring responses and the site-specific geomorphology. Sampling in situ trees with the attendant knowledge of site-specific geomorphic conditions such as was done by Butler and Malanson (1985) provides much better insight into choosing an acceptable Index Number, especially in the case of a limited historical record for comparison. Our case studies reveal that, with a well-developed historical chronology for the local area, we need not depend on the stringent $40 \%$ Index Number cutoff value previously advocated. A $20 \%$ Index Number seems to be appropriate and justified in the context of that historical record.

We are not, however, prepared in our study to accept a $10 \%$ Index Number - not necessarily because we disagree with Dubé et al. (2004), Germain et al. (2005), or Pederson et al. (2006) and Reardon et al. (2008), but simply because our total sample size per avalanche path is small. By accepting a $10 \%$ Index Number, we would be inferring an avalanche event on the basis of a single tree in most cases, and in spite of our belief in the inherent utility of dendrogeomorphological techniques for dating past avalanche events, we are not prepared to infer a recent avalanche on the basis of tree-ring reactions from a solitary tree. Under circumstances such as faced by Stoffel et al. (2006) for the pre-1850 period, we could envision doing so if the tree-ring record from a solitary tree was exceptionally strong, however, we reiterate that 
when it comes to sample size, "more is better". And even with a sample size of perhaps 100 or more trees, an appropriate Index Number must be grounded in a strong knowledge of the local site conditions from which the tree-ring samples were derived, in concert with as thorough a historical record for the local area as possible. In our study area, the good historical record is unfortunately not site-specific to individual avalanche paths, so we advocate the $20 \%$ cutoff. Only with a large sample size and a very strong historical record (which might obviate the necessity for dendrogeomorphological analysis!) could we feel comfortable with a $10 \%$ Index Number.

Acknowledgements. The tree-ring collection described here was funded by a National Science Foundation Small Grant for Exploratory Research in 2001 to Butler, G. P. Malanson, S. J. Walsh, and D. B. Fagre. Malanson, Walsh, and Blase Reardon assisted in the disc collection. A. Sawyer assisted in the preparation of the cross sections for analysis. This paper is a Contribution of the Mountain GeoDynamics Research Group.

Edited by: M. Bollschweiler

Reviewed by: two anonymous referees

\section{References}

Alestalo, J.: Dendrochronological interpretation of geomorphic processes, Fennia, 105, 1-140, 1971.

Boucher, D., Filion, L., and Hétu, B.: Reconstitution dendrochronologique et fréquence des grosses avalanches de neige dans un couloir, subalpine du Mont Hog's Back, Gaspésie centrale (Québec), Géographie physique et Quaternaire, 57(2-3), 159-168, 2003.

Bryant, C. L., Butler, D. R., and Vitek, J. D.: A statistical analysis of tree- ring dating in conjunction with snow avalanches: comparison of on-path versus off-path responses, Environ. Geol. Water S., 9(1), 53-59, 1989.

Burrows, C. J. and Burrows, V. L.: Procedures for the Study of Snow Avalanche Chronology Using Growth Layers of Woody Plants, Boulder, CO, University of Colorado Institute of Arctic Alpine Res. Occasional Paper No. 23, 1976.

Butler, D. R.: Snow avalanche path terrain and vegetation, Glacier National Park, Montana, Arctic Alpine Res., 11(1), 17-32, 1979.

Butler, D. R.: Snow-avalanche hazards in Glacier National Park, Montana: meteorologic and climatologic aspects, Phys. Geography, 7(1), 72-87, 1986a.

Butler, D. R.: Spatial and temporal aspects of the snow avalanche hazard, Glacier National Park, Montana, U.S.A, Proceedings of the International Snow Science Workshop, Homewood, CA, ISSW Workshop Committee, 223-230, 1986b.

Butler, D. R.: Teaching general principles (not principals) and applications of dendrogeomorphology, J. Geol. Educ., 35, 64-69, 1987a.

Butler, D. R.: Snow-avalanche hazards, southern Glacier National Park, Montana: The nature of local knowledge and individual responses, Disasters, 11(3), 214-220, 1987b.
Butler, D. R.: Snow avalanche-dams and resultant hazards in Glacier National Park, Montana, Northwest Sci., 63(3), 109-115, 1989.

Butler, D. R.: Geomorphic process-disturbance corridors: a variation on a principle of landscape ecology, Prog. Phys. Geog., 25(2), 237-248, 2001.

Butler, D. R. and Malanson, G. P.: A history of high-magnitude snow avalanches, southern Glacier National Park, Montana, U.S.A., Mt. Res. Dev., 5(2), 175-182, 1985.

Butler, D. R., Malanson, G. P., and Oelfke, J. G.: Tree-ring analysis and natural hazard chronologies: minimum sample sizes and index values, Prof. Geogr., 39(1), 41-47, 1987.

Carrara, P. E.: The determination of snow avalanche frequency through tree-ring analysis and historical records at Ophir, Colorado, Geol. Soc. Am. Bull., 90(8), 773-780, 1979.

Casteller, A., Stöckli, V., Villalba, R., and Mayer, A. C.: An evaluation of dendroecological indicators of snow avalanches in the Swiss Alps, Arctic, Antarctic, and Alpine Res., 39(2), 218-228, 2007.

Cushman, M. J.: The influence of recurrent snow avalanches on vegetation patterns in the Washington Cascades, Unpublished Ph.D. dissertation, Department of Botany, University of Washington, Seattle, 1981.

Dubé, S., Filion, L., and Hétu, B.: Tree-ring reconstruction of high-magnitude snow avalanches in the northern Gaspé Peninsula, Québec, Canada, Arctic, Antarctic, and Alpine Res., 36(2), 555-564, 2004.

Erschbamer, B.: Vegetation on avalanche paths in the Alps, Vegetatio, 80, 139-146, 1989.

Frazer, G. W.: Dendrogeomorphic Evaluation of Snow Avalanche History at Two Sites in Banff National Park, Unpublished M.Sc. thesis, Department of Geography, University of Western Ontario, London, ON, Canada, 1985.

Germain, D., Filion, L., and Hétu, B.: Snow avalanche activity after fire and logging disturbances, northern Gaspé, Quebec, Canada, Can. J. Earth Sci., 42, 2103-2116, 2005.

Hansen-Bristow, K. and Birkeland, K.: Applications of dendrochronology in avalanche studies, The Avalanche Rev., 7(4), 3-6, 1989.

Hebertson, E. G. and Jenkins, M. J.: Historic climate factors associated with major avalanche years on the Wasatch Plateau, Utah, Cold Reg. Sci. Technol., 37, 315-332, 2003.

Ives, J. D., Mears, A. I., Carrara, P. E., and Bovis, M. J.: Natural hazards in mountain Colorado, Annals Assoc. Am. Geographers, 66(1), 129-144, 1976.

Jenkins, M. J. and Hebertson, E. G.: A practitioner's guide for using dendroecological techniques to determine the extent and frequency of avalanches, in: International Snow Science Workshop, 423-434, Jackson, Wy, 2004.

Johnson, E. A.: The relative importance of snow avalanche disturbance and thinning on canopy plant populations, Ecology, 68(1), 43-53, 1987.

Johnson, E. A., Hogg, L., and Carlson, C. S.: Snow avalanche frequency and velocity for the Kananaskis Valley in the Canadian Rockies, Cold Reg. Sci. Technol., 10, 141-151, 1985.

Kajimoto, T., Daimaru, H., Okamoto, T., Otani, T., and Onodera, H.: Effects of snow avalanche disturbance on regeneration of subalpine Abies mariesii forest, northern Japan, Arctic, Antarctic, and Alpine Research, 36(4), 436-445, 2004. 
Larocque, S. J., Hétu, B., and Filion, L.: Geomorphic and dendroecological impacts of slushflows in central Gaspé Peninsula (Québec, Canada), Geografiska Annaler, 83A(4), 191-201, 2001.

Malanson, G. P. and Butler, D. R.: Avalanche paths as fuel breaks: implications for fire management, J. Environ. Manage., 19(3), 229-238, 1984a.

Malanson, G. P. and Butler, D. R.: Transverse pattern of vegetation on avalanche paths in the northern Rocky Mountains, Montana, Great Basin Naturalist, 44(3), 454-458, 1984b.

Malanson, G. P. and Butler, D. R.: Floristic patterns on avalanche paths in the northern Rocky Mountains, USA, Phys. Geography, 7(3), 231-38, 1986.

Mears, A. I.: Dynamics of dense-snow avalanches interpreted from broken trees, Geology, 3(9), 521-523, 1975.

Mundo, I. A., Barrera, M. D., and Roig, F. A.: Testing the utility of Nothofagus pumilio for dating a snow avalanche in Tierra del Fuego, Argentina, Dendrochronologia, 25(1), 19-28, 2007.

Muntán, E., Andreu, L., Oller, P., Gutiérrez, E., and Martínez, P.: Dendrochronological study of the Canal del Roc Roig avalanche path: first results of the Aludex project in the Pyrenees, Ann. Glaciol., 38(1), 173-179, 2004.

NCDC: National Climate Data Center, accessed through http://cdo. ncdc.noaa.gov/CDO/cdo, 2006.

Niemann, K. O.: Observations of snow avalanche activity in the Kananaskis region, Alberta, The Albertan Geographer, 18, 2942, 1982.

Patten, R. S. and Knight, D. H.: Snow avalanches and vegetation pattern in Cascade Canyon, Grand Teton National Park, Wyoming, USA, Arctic Alpine Res., 26(1), 35-41, 1994.

Pedersen, G. T., Reardon, B. A., Caruso, C. J., and Fagre, D. B.: High resolution tree-ring based spatial reconstructions of snow avalanche activity in Glacier National Park, Montana, USA, 2006 ISSW Proceedings, Telluride, CO, 436-443, 2006.

Potter Jr., N.: Tree-ring dating of snow avalanche tracks and the geomorphic activity of avalanches, northern Absaroka Mountains, Wyoming, Boulder, CO, Geological Society of America, Special Paper 123, 141-165, 1969.

Rayback, S. A.: A dendrogeomorphological analysis of snow avalanches in the Colorado Front Range, USA, Phys. Geography, 19(6), 502-515, 1998.

Reardon, B. A., Fagre, D. B., and Steiner, R. W.: Natural avalanches and transportation: A case study from Glacier National Park, Montana, USA, in: International Snow Science Workshop, 582597, Jackson, WY, 2004.
Reardon, B. A., Pederson, G. T., Caruso, C. J., and Fagre, D. B.: Spatial reconstructions and comparisons of historic snow avalanche frequency and extent using tree rings in Glacier National Park, Montana, U.S.A., Arctic, Antarctic, and Alpine Res., 40(1), 148-160, 2008.

Sandford, H.: The Use of Dendrochronology as an Avalanche Risk Mapping Tool, Unpublished Honors Thesis, Department of Geography, University of Victoria, Victoria, BC, Canada, 1992.

Sawyer, C. F. and Butler, D. R.: A chronology of high-magnitude snow avalanches reconstructed from archived newspapers, Disaster Prevention and Management, 15(2), 313-24, 2006.

Schaerer, P. A.: Terrain and vegetation of snow avalanche sites at Rogers Pass, British Columbia, in: Mountain Geomorphology, edited by: Slaymaker, O. and McPherson, H. J., Vancouver, BC, Tantalus Research Ltd., 215-222, 1972.

Shroder Jr., J. F.: Dendrogeomorphology: review and new techniques of tree-ring dating, Prog. Phys. Geog., 4(2), 161-188, 1980.

Smith, L.: Indication of snow avalanche periodicity through interpretation of vegetation patterns in the North Cascades, Washington, in: Methods of Avalanche Control on Washington Mountain Highways - Third Annual Report, Washington State Highway Commission Department of Highways, 55-101, Olympia, WA, 1973.

Stoffel, M.: A review of studies dealing with tree rings and rockfall activity: The role of dendrogeomorphology in natural hazard research, Nat. Hazards, 39(1), 51-70, 2006.

Stoffel, M. and Bollschweiler, M.: Tree-ring analysis in natural hazards research - an overview, Nat. Hazards Earth Syst. Sci., 8, 187-202, 2008, http://www.nat-hazards-earth-syst-sci.net/8/187/2008/.

Stoffel, M., Bollschweiler, M., and Hassler, G.-R.: Differentiating past events on a cone influenced by debris-flow and snow avalanche activity - a dendrogeomorphological approach, Earth Surf. Processes Landforms, 31, 1427-1434, 2006.

Suffling, R.: Induction of vertical zones in sub-alpine valley forests by avalanche-formed fuel breaks, Landscape Ecology, 8(2), 127$138,1993$.

Ward, R. G. W.: An estimate of avalanche frequency in Glen Feshie, Scotland, using tree rings, in: Palaeoenvironmental Investigations: Research Design, Methods and Data Analysis, edited by: Fieller, N. R. J., Gilbertson, D. D., and Ralph, N. G. A., Symposium Number 5(i) of the Association for Environmental Archaeology, British Archaeological Reports International Series, 258, 237-244, 1985. 